\title{
FAKTOR-FAKTOR YANG BERHUBUNGAN DENGAN KEHAMILAN BERISIKO TINGGI
}

\author{
Rahmadewi ${ }^{1}$ dan Rina Herartri ${ }^{1}$ \\ 1Pusat Penelitian dan Pengembangan Kependudukan, BKKBN
}

\begin{abstract}
ABSTRAK
Masih tingginya angka kematian ibu dan bayi banyak berhubungan dengan kehamilan, persalinan dan pasca persalinan yang terjadi pada wanita yang berisiko. Faktor-faktor yang menyebabkan risiko tinggi pada kehamilan antara lain adalah yang disebut dengan ' 4 Terlalu', yaitu jarak kelahiran terlalu dekat, jumlah persalinan terlalu banyak, serta melahirkan pada usia terlalu tua atau terlalu muda. Tujuan studi ini adalah hubungan mempelajari besar hubungan antara beberapa faktor dengan risiko kehamilan '4 Terlalu'. Studi ini menggunakan data SDKI tahun 2007 terhadap wanita berstatus kawin yang memiliki minimal 2 anak. Jumlah sampel terpilih adalah 9930 orang ibu berstatus kawin. Sebesar 2,7 persen kejadian risiko kehamilan 4 terlalu, adalah umur $<20$ atau $>35$ tahun (31,5 persen), jumlah kehamilan 4 kali atau lebih $(28,7$ persen), dan jarak kelahiran $<24$ bulan (17,8 persen). Analisis bivariat antara faktor sosiodemografi yang berhubungan secara statistik $(p<0,05)$ dengan risiko kehamilan 4-terlalu adalah urutan kelahiran anak, pendidikan ibu, pendidikan suami, indeks kesejahteraan dan tempat tinggal. Faktor pendukung yang berhubungan dengan risiko kehamilan 4-terlalu adalah kualitas asuhan kehamilan (ANC $>4$ kali), penolong persalinan dan kesertaan ber-KB. Analisis multivariat menunjukkan bahwa status pekerjaan ibu merupakan variabel yang dominan yang berhubungan secara bermakna $(p<0,05)$ dengan kejadian risiko kehamilan 4 terlalu. Untuk menghindari kejadian kehamilan 4-terlalu, perlu peningkatan penyuluhan (KIE) dengan strategi yang tepat baik kepada ibu-ibu PUS dan pasangannya maupun kepada remaja. Selain itu perlu upaya pemberian informasi tentang perencanaan keluarga dan umur kawin pertama yang berkaitan dengan Program KB dan kesehatan reproduksi.
\end{abstract}

Kata kunci: kematian ibu, risiko tinggi, risiko kehamilan '4 Terlalu'.

ABSTRACT

\section{FACTORS ASSOCIATED WITH THE HIGH RISK PREGNANCY IN INDONESIA}

Maternal mortality rate (MMR) in Indonesia is currently the highest among Southeast Asian Countries. Many of maternal mortality cases are related to high risk during pregnancy or delivery. The conditions linked to high risk during pregnancies are being too young, too old (over the age of 35), and have experience-too many pregnancies (4 or more), and too close in birth space (less than 2 years), or known as 4-Ts pregnancy. The aim of this study is to identify factors associated to high risk pregnancy in Indonesia. This study was analyzed the 2007 IDHS data, with a total number of 9,980 respondents (married women). The 2007 IDHS data showed that 4-Ts pregnancies occurred in $2.7 \%$ of total pregnancies, with $31.5 \%$ women $<20$ or $>35$ years old, $28.7 \%$ women with 4 or more pregnancies, and $17.8 \%$ women who had birth specify with an interval $<2$ years. The analysis resulted that wife's occupation is the dominant variable for 4-Ts pregnancies $(p<0,05)$. Effective education and information programs on maternal health care, family planning and reproductive health, are needed to address the issues related to 4-Ts pregnancies. These programs should be aimed to prioritize both couples and adolescents. Moreover, it is needed to educate.

Keywords: maternal mortality, high risk pregnancy, 4-Ts pregnancy

\section{PENDAHULUAN}

$\mathrm{M}$ asih tingginya angka kematian ibu dan bayi banyak berhubungan dengan kehamilan, persalinan dan pasca persalinan yang terjadi pada wanita yang berisiko. Angka kematian ibu (AKI) pada saat ini masih tetap tinggi dan tertinggi di Asia termasuk di negara-negara ASEAN. Sebagai contoh, AKI di Malaysia pada tahun 1995 adalah 30, di
Srilanka 30 dan Thailand 50 per 100.000 kelahiran hidup. AKI di Indonesia masih mencapai 228 per 100.000 kelahiran hidup, sedangkan angka kematian bayi (AKB) mencapai 39 per 1000 kelahiran hidup. ${ }^{1}$

Berbagai penyebab AKI, dan AKB di Indonesia karena faktor langsung dan faktor tidak langsung. Faktor langsung ini terkait dengan ilmu pengetahuan dan teknologi di bidang kedokteran. Beberapa hasil survei 
menyebutkan faktor yang berkaitan dengan AKI adalah terjadinya komplikasi pada waktu ibu melahirkan. Faktor langsung tersebut antara lain adalah perdarahan, infeksi, keracunan kehamilan. Sementara faktor langsung penyebab AKB baru lahir terutama disebabkan asfiksia, infeksi dan berat bayi lahir rendah. Hal ini berkaitan dengan kondisi kehamilan, pertolongan persalinan yang aman, dan perawatan bayi baru lahir. Hasil SDKI 2007 menyebutkan penyebab utama komplikasi waktu bersalin adalah perdarahan 16 persen, sebelumnya mencapai 20 persen. ${ }^{1}$

Nampaknya intervensi terhadap faktor langsung tersebut bukan hal yang sulit. Artinya dari sisi kedokteran upaya menurunkan angka kematian itu bukanlah suatu masalah. Namun yang menjadi masalah, adalah faktor tidak langsung, dari sisi demand, antara lain adalah tingkat pendidikan ibu yang rendah, keadaan sosial budaya tidak mendukung, status gizi ibu hamil rendah (40 persen dari ibu hamil menderita anemia). Status gizi yang rendah ini juga terjadi pada neonatal, bayi dan anak. Faktor tidak langsung lain yang berperan adalah kedudukan dan peranan kaum ibu tidak menguntungkan serta transportasi yang tidak mendukung. Dari sisi supply, faktor tidak langsung tersebut mencakup jumlah sarana dan pelayanan maternal, neonatal, bayi dan balita tidak menguntungkan. Kualitas dan efektivitas pelayanan maternal, neonatal, bayi dan balita belum memadai. Demikian pula dengan sistem rujukan yang belum mantap.

Untuk menurunkan AKI perlu disosialisasikan pada keluarga dan masyarakat mengenai pentingnya memahami tiga fase terlambat yang dapat menyebabkan kematian ibu, yaitu: i) Terlambat satu; terlambat memutuskan untuk mencari pertolongan baik secara individu, keluarga atau keduanya. Faktor-faktor yang mempengaruhi fase satu ini adalah terlambat mengenali kehamilan dalam situasi gawat, jauh dari fasilitas kesehatan, biaya, persepsi mengenai kualitas dan efektifitas dari perawatan kesehatan. ii) Terlambat kedua; terlambat mencapai fasilitas pelayanan kesehatan. Faktor-faktor yang mempengaruhi fase kedua ini adalah lama pengangkutan, kondisi jalan, dan biaya transportasi, iii) Terlambat tiga; terlambat mendapatkan pelayanan yang adekuat. Faktorfaktor yang mempengaruhi fase tiga ini adalah terlambat mendapatkan pelayanan pertama kali di rumah sakit (rujukan). Keterlambatan ini dipengaruhi oleh kelengkapan peralatan rumah sakit, ketersediaan obat dan ketersediaan tenaga kesehatan terlatih.

Di samping faktor tiga terlambat, program KB juga berkontribusi terhadap penurunan AKI dan AKB, yaitu menghindari risiko kehamilan 4terlalu. Faktor risiko kehamilan empat terlalu (4T) pada ibu berkaitan dengan umur ibu pada waktu melahirkan kurang dari 20 tahun (terlalu muda), umur ibu pada waktu melahirkan di atas 35 tahun (terlalu tua), ibu yang telah mengalami 4 kali kehamilan atau lebih (terlalu banyak), ibu yang mempunyai jarak kelahiran dengan persalinan sebelumnya kurang dari 24 bulan (terlalu dekat). Pada tahap awal, variabel dependen dikelompokkan menjadi 3 (tiga), yaitu: (1) Umur; (2) Kehamilan; (3) Jarak kelahiran. Data menunjukkan bahwa 12,7 persen perempuan memiliki jarak kelahiran anak kurang dari 24 bulan, 19,3 persen perempuan yang hamil 4 kali atau lebih, 11 persen perempuan masih melahirkan walaupun sudah berusia di atas 35 tahun, dan 10,3 persen perempuan usia di bawah 20 tahun sudah melahirkan. ${ }^{2}$

Bob Berstein mengatakan bahwa risiko kematian bayi atau balita lebih besar pada wanita dengan satu atau lebih risiko kehamilan 4-terlalu 1,74 kali lebih besar dibandingkan dengan wanita yang tidak berisiko. Dikatakan pula bahwa BKKBN telah berhasil dalam membantu para keluarga untuk menurunkan prevalensi kelahiran pada wanita dengan risiko kehamilan 4-terlalu dari 48 persen pada tahun 1991 menjadi 40 persen pada tahun 1997. Lebih lanjut Bob Berstain menyatakan bahwa untuk prevalensi kelahiran yang terjadi di antara para wanita dengan satu risiko kehamilan 4terlalu sebesar 27,1 persen dan risiko relatif kematian balita sebesar 1,60. Adapun prevalensi kelahiran yang terjadi di antara wanita dengan 2-3 risiko kehamilan 4-terlalu sebesar 13 persen dan risiko relatif kematian balita sebesar 2,03. Sedangkan prevalensi kelahiran yang terjadi diantara wanita dengan satu atau lebih risiko kehamilan 4-terlalu sebesar 40,1 persen dan risiko relatif kematian balita sebesar $1,74 .^{3}$

Untuk mengkaji kejadian risiko kehamilan "4-terlalu", seseorang ditentukan oleh niat; dan niat dipengaruhi oleh sikap dan norma sosial 
yang biasanya dipengaruhi oleh faktor pengetahuan, keyakinan dan faktor demografis. Notoatmodjo, dkk. (1989) ${ }^{4}$ menyatakan bahwa merubah atau memotivasi seseorang untuk mau menerima suatu kebiasaan baru bukanlah hal yang mudah. Hal ini berkaitan dengan proses inter-personal, yaitu apa keuntungan yang akan diperoleh bila menerima kebiasaan baru tersebut. Proses inter-personal, yaitu apakah dengan menerima gagasan baru itu tidak tersisih dari kelompoknya. Nilai-nilai yang dianut seseorang bukan saja berdasarkan apa yang dialami dan dianggap baik oleh dirinya tapi juga nilai tersebut telah dianut bersama oleh kelompok dan masyarakat.

Perilaku manusia sebenarnya merupakan refleksi dari beberapa gejala kejiwaan. Apabila ditelusuri lebih lanjut, gejala kejiwaan tersebut diatas ditentukan dan dipengaruhi oleh berbagai faktor lain, di antaranya adalah faktor pengalaman, keyakinan, sarana fisik, sosio budaya masyarakat dan sebagainya. ${ }^{5}$

Menurut Lawrence Green (1980) dalam Notoatmodjo (1993), faktor-faktor yang dapat mempengaruhi perilaku adalah: ${ }^{5}$

1. Faktor predisposisi (sosio-demografi), yaitu faktor pencetus timbulnya perilaku, pikiran dan motivasi untuk berperilaku yang meliputi pengetahuan, sikap, kepercayaan, keyakinan, nilai dan persepsi yang berhubungan dengan motivasi individu untuk berperilaku.

2. Faktor pemungkin/ pendukung (enabling factors), adalah faktor yang mendukung timbulnya perilaku sehingga motivasi atau pikiran menjadi kenyataan, termasuk didalamnya adalah lingkungan fisik dan sumber-sumbernya yang ada di masyarakat.

3. Faktor penguat/ pendorong (reinforcing factors), yaitu faktor yang merupakan sumber pembentukan perilaku yang berasal dari orang lain yang merupakan kelompok referensi dari perilaku seperti keluarga, teman, guru atau petugas kesehatan.

Sebagai upaya penyelamatan ibu ("Safe Motherhood Initiative") telah banyak dilakukan program kesehatan dan KB-KR, terutama melalui MPS ("Making Preqnancy Safer"). Ada 3 (tiga) pesan kunci MPS, yaitu 1) setiap persalinan ditolong oleh tenaga kesehatan terlatih; 2) setiap komplikasi obstetri dan neonatal mendapat pelayanan yang adekuat; 3) setiap wanita usia subur (WUS) akses terhadap pencegahan kehamilan tidak diinginkan (KTD) dan penanganan komplikasi keguguran. Pada kenyataannya, belum semua ibu akses ke pelayanan. Bahkan masih ditemui ibu hamil dan melahirkan pada usia di bawah 20 tahun atau di atas 35 tahun, jarak kehamilannya terlalu dekat (kurang dari 3 tahun), dan ibu masih masa reproduksi telah memiliki anak yang lebih dari 3 orang. Untuk itu analisis ini mengkaji kejadian kehamilan 4-T dikaitkan dengan karakteristik ibu dan faktor-faktor yang mempengaruhinya. Tujuan penelitian adalah untuk mempelajari besar hubungan antara beberapa faktor dengan risiko kehamilan empat terlalu (4T).

\section{METODE PENELITIAN}

Penelitian ini merupakan studi analitik terhadap data sekunder dari "Survei Demografi dan Kesehatan Indonesia (SDKI)" tahun 2007.1 Data tersebut dikumpulkan oleh Badan Pusat Statistik (BPS), dan pelaksanaan penelitian merupakan kerjasama antara BKKBN, Kementerian Kesehatan dan BPS. Disain yang digunakan dalam penelitian ini adalah studi "cross-sectional" (potong lintang), yang mengukur variabel independen dan variabel dependen pada waktu yang sama.

Kerangka konsep yang digunakan dalam analisis ini menggunakan landasan teori Notoatmodjo (1993) dan Lawrence Green (1980), namun disesuaikan dengan variabel yang tersedia di dalam kuesioner SDKI 2007.1,5 Variabel yang digunakan adalah sebagai berikut:

1. Faktor predisposisi (sosio-demografi): urutan kelahiran anak, jenis kelamin anak, umur kawin pertama, umur ketika melahirkan anak pertama, pendidikan ibu, pendidikan suami, status pekerjaan ibu, status pekerjaan suami, indeks kesejahteraan (komposit) dan tempat tinggal (desa/kota).

2. Faktor pemungkin/pendukung (enabling factors): terpapar dengan media massa, kualitas asuhan kehamilan (ANC), penolong persalinan, keikutsertaan ber-KB dan penyapihan (lama pemberian) ASI. 
3. Faktor penguat/pendorong (reinforcing factors): Mengunjungi fasilitas kesehatan, kunjungan petugas lapangan tentang $\mathrm{KB}$, dan kontak dengan petugas tentang masalah alat/cara KB

Populasi adalah seluruh wanita berstatus kawin atau wanita PUS. Adapun sampel dalam analisis ini, diambil secara selektif, yaitu wanita berstatus kawin yang memiliki minimal dua anak. Seluruh jumlah sampel terpilih adalah 9980 orang ibu berstatus kawin. Pengolahan dan analisis data dilakukan secara kuantitatif berdasarkan analisis univariat, bivariat dan multivariat.

\section{HASIL DAN BAHASAN}

\section{Gambaran Kejadian Risiko Kehamilan 4- Terlalu}

Penyebab kematian ibu antara lain adalah karena akibat 3-Terlambat yaitu (terlambat mengambil keputusan, terlambat membawa ke fasilitas pelayanan, dan terlambat dalam menangani dan mengetahui tanda bahaya (komplikasi/ kegawatdaruratan hamil, persalinan dan nifas). Di samping itu juga akibat adanya risiko kehamilan 4-Terlalu yaitu karena terlalu sering melahirkan, terlalu banyak anak, terlalu muda melahirkan, dan terlalu tua waktu melahirkan. Di samping itu juga harus diperhatikan bahwa kematian terbanyak terjadi dalam waktu dua jam semasa persalinan dan pasca persalinan.

Kejadian wanita yang berisiko kehamilan 4terlalu adalah hampir 3 persen tepatnya 2,7 persen. Persentasenya meningkat dibandingkan SDKI 2002-2003, yaitu 1,7 persen. $^{2}$ Berarti kejadian wanita dengan kehamilan berisiko ada kecenderungan terjadi peningkatan. Berarti risiko responden terhadap kejadian kematian demikian besar baik bagi dirinya sendiri (kematian ibu) maupun anak yang akan dilahirkannya (kematian bayi). Pengalaman menyebutkan ada keterkaitan antara kematian ibu dan kematian bayi.

Biran Affandi $(2000)^{6}$ menyebutkan bahwa waktu yang paling aman untuk melahirkan bagi seorang perempuan adalah antara umur 20 tahun dan 35 tahun. Sedangkan untuk umur kurang dari 20 tahun atau di atas 35 tahun dapat dikatakan sudah termasuk berisiko tinggi, di mana keadaan ini akan sangat dipengaruhi oleh keadaan sosial ekonomi dan lingkungan setempat. Satu hal yang jelas adalah, dimana saja angka kematian dan kesakitan ibu akan tinggi bila melahirkan terlalu muda atau terlalu tua.

Tabel 1 menunjukkan bahwa kejadian kehamilan 4-terlalu menurut umur, menunjukkan responden yang berumur kurang dari 20 tahun dan lebih dari 35 tahun yang mempunyai risiko kehamilan 4-terlalu, sebesar 31,5 persen. Menurut jumlah kelahiran $\geq 4$ kali risiko kehamilan 4-terlalu sebesar 28,7 persen.

Tabel 1

Persentase Responden dengan Risiko Kehamilan 4-T menurut Faktor Kejadian 3-T, 2007

\begin{tabular}{llc}
\hline Kejadian Kehamilan 4-T & $\mathrm{n}$ & Persen \\
\hline Umur IBU & & \\
$\quad<20$ tahun atau > 35 tahun & 3139 & 31,5 \\
$\quad 20$ tahun s/d 35 tahun & 6841 & 68,5 \\
\hline $\begin{array}{l}\text { Jumlah Kehamilan } \\
\quad \text { 4 kali }\end{array}$ & 2863 & \\
$\quad$ < 4 kali & 7117 & 28,7 \\
\hline Jarak Kelahiran & & \\
$\quad$ < 24 Bulan & 1772 & 17,8 \\
$\quad>24$ Bulan & 8208 & 82,2 \\
\hline Total & 9980 & 100,0 \\
\hline
\end{tabular}


Jarak kelahiran yang terlalu dekat $(\leq 24$ bulan) juga merupakan salah satu faktor penyebab kehamilan 4-terlalu. Hasil analisis menunjukkan bahwa jarak kelahiran $\leq 24$ bulan menunjukkan angka sebesar 17,8 persen. Nampaknya masih perlu ditingkatkannya kegiatan KIE yang menyangkut pemberdayaan pemahaman perempuan/ keluarga/ masyarakat akan risiko kehamilan "4-terlalu" terhadap kesakitan dan kematian ibu pada waktu persalinan dan nifas. Risiko kematian ibu akan lebih kecil apabila melahirkan pada umur 20-30 tahun, sedikit meningkat pada umur 30-34 tahun dan jelas meningkat pada umur 35 tahun atau lebih.

Sebagaimana dinyatakan oleh Fathalla, MF. dkk (1990, 1997)7,8 dan Diczfalusy, $E$. $(1997)^{9}$, bahwa penyebab kematian ibu karena hamil, bersalin dan nifas dapat dibagi menjadi tiga penyebab yaitu penyebab langsung (karena perdarahan, infeksi, eklamsi, dan persalinan lama), penyebab antara (intermediate), dan penyebab tidak langsung yaitu karena anemia gizi, kehamilan "4-T", kejadian "3-T", faktor sosial, ekonomi, budaya, termasuk bias jender dan faktor geografis. Penyebab langsung dipengaruhi penyebab antara yaitu keadaan gizi, pelayanan KB dan perilaku kesehatan reproduksi. Penyebab antara dipengaruhi oleh penyebab tidak langsung yaitu status perempuan, ekonomi, politik, sosial dan budaya. Dalam analisis selanjutnya faktor-faktor tersebut akan dilihat hubungannya dengan risiko kehamilan 4-T.

\section{Gambaran Faktor Sosio Demografi (Prediposing Factors) yang Berisiko Mengalami Kehamilan 4-Terlalu}

Gambaran responden dengan risiko kehamilan 4-Terlalu menurut faktor sosio demografi disajikan pada Tabel 2.

Tabel 2

Persentase Responden dengan Risiko Kehamilan 4-Terlalu menurut Faktor Sosio Demografi, 2007

\begin{tabular}{|c|c|c|}
\hline Sosial demografi & $\mathrm{n}$ & Persen \\
\hline \multicolumn{3}{|l|}{ Urutan Kelahiran Anak } \\
\hline$>2$ Anak & 5072 & 50,8 \\
\hline$\leq 2$ Anak & 4908 & 49,2 \\
\hline \multicolumn{3}{|l|}{ Jenis Kelamin Anak } \\
\hline Laki Laki & 5189 & 50.2 \\
\hline Perempuan & 4791 & 48.0 \\
\hline \multicolumn{3}{|l|}{ Umur Kawin Pertama } \\
\hline$<20$ dan $>35$ Tahun & 5718 & 57,3 \\
\hline 20 - 35 Tahun & 4262 & 42,7 \\
\hline \multicolumn{3}{|l|}{ Pendidikan Ibu } \\
\hline Rendah & 5413 & 54,2 \\
\hline Tinggi & 4567 & 45,8 \\
\hline \multicolumn{3}{|l|}{ Pendidikan Suami } \\
\hline Rendah & 4911 & 49,2 \\
\hline Tinggi & 5069 & 50,8 \\
\hline \multicolumn{3}{|l|}{ Status Pekerjaan Ibu } \\
\hline Tidak Bekerja & 9664 & 96,8 \\
\hline Bekerja & 316 & 3,2 \\
\hline \multicolumn{3}{|l|}{ Status Pekerjaan Suami } \\
\hline Tidak bekerja & 192 & 1,9 \\
\hline Bekerja & 9788 & 98,1 \\
\hline \multicolumn{3}{|l|}{ Indeks Kesejahteraan *) } \\
\hline Rendah & 4291 & 43,0 \\
\hline Sedang & 1966 & 19,7 \\
\hline Tinggi & 3723 & 37,3 \\
\hline \multicolumn{3}{|l|}{ Tempat Tinggal } \\
\hline Pedesaan & 4047 & 40,6 \\
\hline Perkotaan & 5933 & 59,4 \\
\hline Total & 9980 & 100,0 \\
\hline
\end{tabular}


Tabel 2 menunjukkan bahwa faktor sosio demografi responden menurut urutan kelahiran anak, lebih dari dua dan urutan kelahiran anak kedua atau kurang tidak jauh berbeda. Untuk jenis kelamin anak terakhir laki-laki dan anak perempuan yang dimiliki responden terdapat perbedaan, yaitu 52 persen responden yang memiliki anak laki-laki dan 48 persen responden yang memiliki anak perempuan. Menurut umur pertama kali kawin ( $<20$ dan $35+$ tahun) responden nampaknya presentasenya lebih besar dibandingkan dengan responden yang kawin pertamanya 20-35 tahun, yaitu 57,3 berbanding 42,7 persen.

Pendidikan ibu merupakan salah satu faktor yang berpengaruh secara tidak langsung terhadap risiko kehamilan 4-terlalu. Pada tabel yang sama, bahwa responden ibu dengan pendidikan rendah (tamat SLTP ke bawah) rendah dibandingkan ibu yang memiliki pendidikan tinggi (SLTA ke atas), yaitu 54,2 berbanding 45,8 persen. Kecenderungan yang sama dijumpai pada responden dengan risiko kehamilan 4-T yang suaminya berpendidikan rendah, yaitu 49,2 persen responden yang suaminya berpendidikan rendah dan 50,8 persen responden yang suaminya berpendidikan tinggi. Hal ini berpengaruh terhadap akses mereka terhadap segala bentuk informasi termasuk informasi tentang kesehatan dan $\mathrm{KB}$, karena dari data empiris pendidikan sangat berpengaruh terhadap meningkatnya status kesehatan seseorang.

Pekerjaan ibu merupakan salah satu faktor tidak langsung terhadap risiko kehamilan 4terlalu. Gambaran responden tentang status pekerjaan, bahwa sebagian besar yaitu 96,8 persen ibu tidak bekerja dan hanya 3,2 persen ibu bekerja. Sebaliknya status pekerjaan suami, umumnya bekerja sebanyak 98,1 persen.

Indeks kesejahteraan dalam suatu keluarga umumnya berpengaruh dalam peningkatan kualitas SDM termasuk dampaknya terhadap perilaku risiko kehamilan 4-terlalu pada seorang ibu. Namun tidak memperlihatkan kecenderungan semakin tinggi indeks kesejahteraan dan semakin rendah risiko kehamilan 4-terlalu, tetapi kecenderungannya berbentuk huruf $U$, yaitu responden yang memiliki indeks kesejahteraan sedang $(19,7$ persen) persentase risiko kehamilan 4-terlalu lebih rendah dibandingkan dengan responden yang memiliki indeks kesejahteraan rendah (43,0 persen) dan tinggi ( 37,3 persen).

Daerah tempat tinggal juga merupakan salah satu faktor tidak langsung terhadap risiko kehamilan 4-terlalu, hal ini diduga adanya pengaruh jarak terhadap tempat pelayanan. Namun keadaan ini tidak nampak lagi pada hasil analisis, bahwa responden yang tinggal di perkotaan lebih tinggi dibandingkan di pedesaan, yaitu 59,4 berbanding 40,6 persen. Berarti prasarana dan sarana responden untuk akses ke fasilitas kesehatan dan untuk mendapatkan berbagai informasi sudah jauh lebih baik dibandingkan dengan survei terdahulu.

Analisis bivariat antara variabel sosiodemografi dengan kejadian risiko kehamilan 4terlalu, bahwa urutan kelahiran anak, pendidikan ibu, pendidikan suami, indeks kesejahteraan dan tempat tinggal memiliki hubungan yang signifikan $(p<0,05)$ dengan risiko kehamilan 4-terlalu.

\section{Gambaran Faktor Pendukung yang Berisiko Mengalami Kehamilan/ Persalinan 4 Terlalu}

Variabel faktor pendukung, adalah kualitas asuhan kehamilan (ANC), penolong persalinan, keikutsertaan dalam ber-KB dan lama pemberian ASI (Tabel 3).

Apabila dibandingkan hasil SKRT 1995 menunjukkan adanya penurunan, pada SKRT 1995 hanya 78 persen ibu hamil yang kualitas memeriksakan kehamilannya selama hamil, sedangkan dari hasil analisis ini yang memeriksakan kehamilan mencapai 62 persen, dan angka ini juga menurun dibandingkan dengan hasil SDKI 2002-2003 (92 persen). 10,2

Sebagaimana telah dicanangkannya Making Pregnancy Safer (MPS) pada tahun 2000, bahwa pada tahun 2005 telah ditargetkan untuk mencapai persalinan oleh tenaga terlatih sebesar 80 persen dan menurunkan angka kematian yang berhubungan dengan persalinan sebesar 75 persen pada tahun 2015. Analisis ini menunjukkan responden yang melahirkan ditolong oleh tenaga kesehatan (Nakes), yang penolong persalinan dilakukan oleh tenaga medis (dokter/ bidan) sebanyak 71,5 persen. Apabila dikaitkan dengan program MPS angka tersebut belum mencapai target MPS, tetapi sedikit lebih tinggi bila dibandingkan dengan pencapaian angka SDKI 2002-2003 yaitu 55 persen. $^{2}$ 
Tabel 3

Persentase Responden Dengan Risiko Kehamilan 4-T menurut Faktor Pendukung, 2007

\begin{tabular}{lcc}
\hline Faktor Pendukung & $\mathrm{n}$ & Persen \\
\hline Kualitas Asuhan Kehamilan & & \\
Tidak & 3788 & 38.0 \\
Ya & 6192 & 62.0 \\
\hline Penolong Persalinan & & \\
Dukun / keluarga & 2846 & 28.5 \\
Dokter /Bidan & 7134 & 71.5 \\
\hline Kesertaan ber-KB & & \\
Tidak & 828 & 8.3 \\
Ya & 9152 & 91.7 \\
\hline Penyapihan (lama Pemberian ASI) & & \\
Kurang dari 24 Bulan & 2961 & 29.7 \\
$>=24$ Bulan & 7019 & 70.3 \\
\hline Total & 9980 & 100.0 \\
\hline
\end{tabular}

Di samping variabel di atas masih banyak faktor yang dapat menentukan penurunan angka dan rasio kematian ibu. Program jangka panjang penurunan angka dan rasio kematian ibu adalah kombinasi antara pendidikan, peningkatan status wanita serta kesertaan ber$\mathrm{KB}$ dalam upaya perencanaan kehamilan yang aman/ kehamilan yang diinginkan. Hampir semua responden telah ber KB, yaitu 91,7 persen, dan hanya 8,3 persen ibu yang belum ber-KB. Persentase ini lebih tinggi apabila dilihat dari hasil SDKI 2002-2003 hanya 60 persen. ${ }^{2}$

Faktor pemberian ASI oleh seorang ibu terhadap risiko akan mengalami kehamilan 4terlalu, memperlihatkan persentase yang berbeda antara ibu yang memberikan ASI selama kurang dari 24 bulan dan ibu yang memberikan ASI 24 bulan atau lebih, yaitu 29,7 dan 70,3 persen. Lamanya pemberian ASI oleh seorang ibu kepada anaknya akan mempengaruhi lamanya masa postpartum amenore, berarti ada tenggang waktu tidak subur setelah ibu melahirkan.

Analisis bivariat antara variabel pendukung dengan kejadian kehamilan 4-terlalu, bahwa kualitas asuhan kehamilan (ANC> 4 kali), penolong persalinan dan kesertaan ber-KB memiliki hubungan secara statitisk $(p<0,05)$ dengan kehamilan 4-terlalu. Sedangkan lama pemberian ASI tidak berhubungan secara statistik dengan kejadian kehamilan 4-terlalu $(p>0,05)$.

\section{Gambaran Faktor Pendorong (Reinforcing Factors) Yang Berisiko Mengalami Kehamilan 4- Terlalu}

Faktor pendorong (reinforcing factors) dari data SDKI 2007 banyak berkaitan dengan akses responden pada fasilitas dan tenaga kesehatan dan $\mathrm{KB}$, yaitu apakah responden mengunjungi fasilitas kesehatan, kunjungan petugas lapangan yang membicarakan tentang $\mathrm{KB}$, dan kontak responden dengan petugas tentang masalah alat/ cara KB.

Persentase yang perbedaannya mencolok adalah pada responden yang tidak kontak dengan petugas yaitu 86,2 persen akan berisiko mengalami kehamilan 4-terlalu. Responden yang mengunjungi fasilitas kesehatan dan kunjungan petugas lapangan persentasenya relatif hampir sama terhadap risiko akan mengalami kehamilan 4-terlalu (Tabel 4).

Analisis bivariat hubungan antara variabel pendorong dengan kejadian risiko kehamilan 4terlalu, bahwa semua variabel tersebut tidak berhubungan dengan risiko kehamilan 4-terlalu adalah nilai $p>0,05$. 
Tabel 4

Persentase Responden Dengan Risiko Kehamilan 4-T Menurut Faktor Pendorong, 2007

\begin{tabular}{lcc}
\hline Faktor Pendorong & $\mathrm{n}$ & Persen \\
\hline Mengunjungi Fasilitas Kesehatan & & \\
Tidak & 5108 & 51,2 \\
Ya & 4872 & 48,8 \\
\hline Kunjungan Petugas Lapangan Tentang KB & & \\
Tidak & 9378 & 94,0 \\
Ya & 602 & 6,0 \\
\hline Kontak dgn Petugas Masalah alat / cara KB & & \\
Tidak & 8602 & 86,2 \\
Ya & 1378 & 13.8 \\
\hline Total & 9980 & 100.0 \\
\hline
\end{tabular}

\section{Analisis Multivariat}

Analisis multivariat antara faktor sosiodemografi, pendukung dan pendorong secara bersama yang berhubungan secara statistik $(p<0,05)$ dengan kejadian risiko kehamilan 4terlalu adalah status pekerjaan ibu, indeks kesejahteraan, dan kualitas asuhan kehamilan, kesertaan ber-KB. Berarti ibu yang tidak bekerja, ibu yang tidak sejahtera, ibu yang tidak melakukan kualitas asuhan kehamilan dan ibu yang tidak ber-KB berpeluang mengalami kehamilan 4 terlalu. Variabel yang paling dominan dengan nilai $\mathrm{OR}$ terbesar adalah status pekerjaan ibu. Artinya ibu yang tidak bekerja mempunyai risiko sebesar 3,8 kali untuk mengalami risiko kehamilan 4-terlalu dibandingkan ibu yang bekerja.

\section{SIMPULAN DAN SARAN}

\section{Simpulan}

Sebesar 2,7 persen ibu yang memiliki 2 orang anak mengalami kejadian risiko kehamilan 4-terlalu. Faktor sosio-demografi yang berhubungan bermakna secara statistik $(p<0,05)$ dengan risiko kehamilan 4-terlalu adalah urutan kelahiran anak, pendidikan ibu, pendidikan suami, indeks kesejahteraan, dan tempat tinggal. Faktor pendukung (enabling factors) yang berhubungan dengan risiko kehamilan 4-T adalah kualitas asuhan kehamilan (ANC), penolong dan keikutsertaan ber-KB. Faktor pendorong (reinforcing factors) tidak ada yang berhubungan dengan risiko kehamilan 4-terlalu.

Analisis multivariat antara faktor sosiodemografi, pendukung dan pendorong yang berhubungan bermakna secara statistik $(p<0,05)$ dengan kejadian risiko kehamilan 4terlalu adalah status pekerjaan ibu, indeks kesejahteraan, kualitas asuhan kehamilan, dan kesertaan ber-KB terhadap kejadian kehamilan 4-terlalu. Hasil analisis multivariat tersebut, variabel status pekerjaan ibu, memiliki peluang paling besar terhadap kejadian kehamilan 4terlalu dibandingkan dengan variabel indeks kesejahteraan, kualitas asuhan kehamilan, dan kesertaan ber-KB. Dengan OR=3,8, artinya ibu yang tidak bekerja berpeluang 3,8 kali mengalami kehamilan 4-terlalu dibandingkan dengan ibu bekerja.

\section{Saran}

Dalam rangka penurunan angka kematian ibu dan bayi, perlu peningkatan penyuluhan (KIE) dengan strategi yang tepat baik pada ibuibu PUS dan pasangannya maupun remaja tentang materi risiko kehamilan 4-terlalu. Risiko kehamilan yang tidak diinginkan, perlunya upaya peningkatan berbagai informasi terutama tentang perencanaan keluarga dan umur kawin pertama yang berkaitan dengan Program KB$\mathrm{KR}$. Keikutsertaan ber-KB dan kualitas asuhan kehamilan (ANC) mempengaruhi risiko kehamilan 4-terlalu, maka perlu menekankan kembali betapa pentingnya kualitas asuhan 
kehamilan (ANC) bagi ibu PUS dan pasangannya baik ketepatan waktu dan frekuensinya maupun tindakan/intervensi termasuk substansi KB pada waktu asuhan kehamilan (ANC).

\section{RUJUKAN}

1. Badan Pusat Statistik, BKKBN, DepKes RI dan Macro International Inc. Survei Demografi dan Kesehatan Indonesia Tahun 2007, BPS, Jakarta: Desember 2008.

2. Badan Pusat Statistik, BKKBN, DepKes RI dan Macro International Inc. Survei Demografi dan Kesehatan Indonesia Tahun 2002-2003, BPS, Jakarta: Desember 2003.

3. Bob Bernstein. Prevalensi "High Risk Fertility Behaviors (H-RFB)" Di Indonesia: Suatu Indikator Kinerja Program KB Dalam Penurunan Kematian Balita, Management Sciences for Health Indonesia Management \& Leadership Program, MSH.

4. Notoatmodjo, S. 1989. Pengantar Pendidikan dan IImu Perilaku Kesehatan. Jakarta: CV Rajawali.
5. Notoatmodjo, S. 1993. Pengantar Pendidikan dan IImu Perilaku Kesehatan. Yogyakarta: Andi Offset.

6. Biran Affandi. Kesehatan Reproduksi: Pidato Pengukuhan Guru Besar Tetap IImu Obstetri dan Ginekologi. Fakultas Kedokteran Universitas Indonesia (FK-UI): 20 Juni 2000.

7. Fathalla, MF.; Rosenfield, A.; Indriso, C.; Ratnam, SS. Reproductive Health Global Issues, The FIGO Manual of Human Reproduction, New Jersey (USA): The Parthenon Publishing; 1990.

8. Fathalla, MF. From Obstetrics and Gynaecology to Women's Health, New York (USA): The Parthenon Publishing; 1997.

9. Diczfalusy, E. The Contraceptive Revolution. New York (USA): The Parthenon Publishing; 1997.

10. Departemen Kesehatan RI. 1997. Survei Kesehatan Rumah Tangga (SKRT) tahun 1995. Jakarta. 